\title{
DNA Methylation Regulates Cocaine-Induced Behavioral Sensitization in Mice
}

\author{
Kaili Anier', Kristina Malinovskaja', Anu Aonurm-Helm', Alexander Zharkovsky' and Anti Kalda*,' \\ 'Department of Pharmacology, University of Tartu, Tartu, Estonia
}

\begin{abstract}
The behavioral sensitization produced by repeated cocaine treatment represents the neural adaptations underlying some of the features of addiction in humans. Cocaine administrations induce neural adaptations through regulation of gene expression. Several studies suggest that epigenetic modifications, including DNA methylation, are the critical regulators of gene expression in the adult central nervous system. DNA methylation is catalyzed by DNA methyltransferases (DNMTs) and consequent promoter region hypermethylation is associated with transcriptional silencing. In this study a potential role for DNA methylation in a cocaine-induced behavioral sensitization model in mice was explored. We report that acute cocaine treatment caused an upregulation of DNMT3A and DNMT3B gene expression in the nucleus accumbens (NAc). Using methylated DNA immunoprecipitation, DNA bisulfite modification, and chromatin immunoprecipitation assays, we observed that cocaine treatment resulted in DNA hypermethylation and increased binding of methyl CpG binding protein 2 (MeCP2) at the protein phosphatase-I catalytic subunit (PP/c) promoter. These changes are associated with transcriptional downregulation of PPIC in NAc. In contrast, acute and repeated cocaine administrations induced hypomethylation and decreased binding of MeCP2 at the fosB promoter, and these are associated with transcriptional upregulation of fosB in NAc. We also found that pharmacological inhibition of DNMT by zebularine treatment decreased cocaine-induced DNA hypermethylation at the PP/C promoter and attenuated PPI c mRNA downregulation in NAc. Finally, zebularine and cocaine co-treatment delayed the development of cocaine-induced behavioral sensitization. Together, these results suggest that dynamic changes of DNA methylation may be an important gene regulation mechanism underlying cocaine-induced behavioral sensitization.

Neuropsychopharmacology (2010) 35, 2450-246I; doi:10.1038/npp.2010.128; published online 18 August 2010
\end{abstract}

Keywords: DNA methylation; DNA methyltransferase; cocaine; behavioral sensitization; nucleus accumbens; zebularine

\section{INTRODUCTION}

Repeated administration of psychostimulants, such as cocaine or amphetamine, induces an enhanced behavioral response to subsequent drug exposure, a phenomenon known as psychomotor or behavioral sensitization that can persist for months (Robinson and Berridge, 1993; Pierce and Kalivas, 1997). Psychostimulant-induced behavioral sensitization in rodents provides a model for addictive behaviors such as those associated with craving and relapse, as well as for psychotic complications of psychostimulant abuse (Koob and Bloom, 1988; Robinson and Berridge, 1993).

Persistent behavioral sensitization after repeated psychostimulant treatment indicates that drug-induced short- and long-term changes in gene expression may be involved (Nestler and Aghajanian, 1997). Recently, new concepts

* Correspondence: Dr A Kalda, Department of Pharmacology, University of Tartu, 19 Ravila Street, Tartu, 504I I Estonia, Tel: +372 7374 353, Fax: + 3727374 352, E-mail: anti.kalda@ut.ee

Received II May 20 I0; revised 10 July 20 I0; accepted 10 July 2010 have emerged about chromatin modification and gene regulation in dividing and non-dividing cells. Chromatinrelated modifications of gene expression patterns have been shown to be important for the long-lasting effects of psychostimulants on the brain (Kumar et al, 2005; BramiCherrier et al, 2005; Renthal et al, 2007; Renthal et al, 2008; Renthal and Nestler, 2008; Shen et al, 2008; Stipanovich et al, 2008; Renthal et al, 2009).

Over the past few years much attention has been paid to the role of histone acetylation and phosphorylation on chromatin modification in psychostimulant-induced neuroadaptations; however, there are no data concerning DNA methylation. The most common form of DNA alteration is the addition of a methyl group to the 5 position of cytosine, catalyzed by DNA methyltransferases (DNMTs) (Bestor, 2000). Cytosine methylation takes place almost exclusively at a cytosine located $5^{\prime}$ to guanine: cytosine-phosphoguanine (CpG) (Singal and Ginder, 1999). The CpG dinucleotides are unevenly distributed: in mammalian genomes they are clustered in so-called CpG islands - short regions of 0.5 to $4 \mathrm{~kb}$ in length having a rich $(60-70 \%)$ cytosine-guanine content. Over $50 \%$ of all dinucleotides in 
these islands are $\mathrm{CpG}$, compared with the rest of the genome where the CpG content is $\leqslant 20 \%$ (Bird, 2002). About $50 \%$ of CpG islands are located in the promoter regions and around the transcription start sites and are unmethylated in normal cells. The change from unmethylated to methylated $\mathrm{CpG}$ islands is recognized as an essential contributor to transcriptional silencing (Robertson and Wolffe, 2000; Jones and Baylin, 2002).

In mammalian cells, two classes of DNMTs catalyze DNA methylation. DNA methyltransferase-1 (DNMT1) is essential for maintaining DNA methylation patterns in proliferating cells and is also involved in establishing new DNA methylation patterns (de novo methylation) (Bestor, 2000; Goll and Bestor, 2005; Siedlecki and Zielenkiewicz, 2006). Members of the second class of methyltransferases, DNMT3A and DNMT3B, are also required for de novo methylation.

In this study, we investigated whether cocaine treatment changes DNMT expression in the nucleus accumbens (NAc), whether DNA methylation regulates protein phosphatase-1 catalytic subunit (PP1c) and fosB gene transcription in the NAc after acute and repeated cocaine treatment, and whether a pharmacological inhibition of DNMT alters the development of behavioral sensitization in mice.

\section{MATERIALS AND METHODS}

\section{Animals}

All experiments were performed in accordance with the EU guidelines (directive 86/609/EEC) on the ethical use of animals using the experimental protocol approved by the Faculty of Medicine of the University of Tartu. Male C57BL/ 6 mice (weight 25-30 g) were obtained from Scanbur BK (Karlslunde, Sweden) and were maintained in temperatureand humidity-controlled rooms with $12 \mathrm{~h}$ light-dark cycle (light from 0700 to $1900 \mathrm{~h}$ ). Animals were allowed access to rodent chow and water ad libitum. They were allowed to acclimate to laboratory conditions and were handled at least 4 days before use in behavioral experiments (which were conducted during the light phase of the light-dark cycle).

\section{Behavioral Procedures}

Horizontal locomotor activity was assessed in standard polypropylene cages $(15 \times 25 \mathrm{~cm})$ uniformly illuminated with dim lighting. A light-sensitive video camera, connected to a computer, was mounted about $1.5 \mathrm{~m}$ above the observation cage and locomotor activity of eight animals in time was monitored and analyzed using VideoMot2 software (TSE Systems, Bad Homburg, Germany).

For experiments investigating the effect of acute and repeated cocaine treatment, animals were randomly assigned to the following treatment groups: (1) 'SAL', mice were treated for 7 days with sterile saline $0.1 \mathrm{ml}$ per $10 \mathrm{~g}$ body weight intraperitoneally (i.p.); (2) acute cocaine 'AC', mice were treated for 6 days with saline and on the seventh day with cocaine hydrochloride $(15 \mathrm{mg} / \mathrm{kg}$, i.p., Oriola Oy, Espoo, Finland); (3) repeated cocaine ' $\mathrm{RC}$ ', mice were treated for 7 days with cocaine $(15 \mathrm{mg} / \mathrm{kg}$, i.p.). On the first and seventh treatment days, locomotor activity was recorded for $60 \mathrm{~min}$ after the last injection. On the second through to the sixth treatment days, mice were injected with the drugs and placed in the test cages for $60 \mathrm{~min}$ without locomotion recording.

For experiments investigating the effect of inhibition of DNMTs, intracerebroventricular (i.c.v.) infusions of zebularine (300 ng per $0.5 \mu \mathrm{l}$; Tocris Bioscience, Bristol, UK) or saline $(0.5 \mu \mathrm{l})$ were performed $20 \mathrm{~min}$ before cocaine ( $15 \mathrm{mg} / \mathrm{kg}$ i.p.) or saline $(0.1 \mathrm{ml}$ per $10 \mathrm{~g}$ body weight, i.p.) treatment. Zebularine and cocaine were freshly prepared in sterile saline. Mice were randomly assigned to the following treatment groups: (1) saline (i.c.v.) + saline (i.p.) ' $S+S$ '; (2) zebularine (i.c.v.) + saline (i.p.) ' $\mathrm{Z}+\mathrm{S}$ '; (3) saline (i.c.v.) + cocaine (i.p.) ' $\mathrm{S}+\mathrm{C}$ '; and (4) zebularine (i.c.v.) + cocaine (i.p.) ' $\mathrm{Z}+\mathrm{C}$ '. Locomotor activity was recorded for $60 \mathrm{~min}$ after i.p. injection, daily for 7 days.

\section{Intracerebroventricular Cannula Implantation}

For cannula implantation, mice were anesthetized with Hypnorm (VetaPharma, Leeds, UK) and Dormicum (Roche, Basel, Switzerland). During surgery each mouse was implanted with a 26-gauge bilateral stainless steel guide cannula (Plastics One, Roankoke, VA, USA) from which the injector extended $0.5 \mathrm{~mm}$ to end in the ventricle. Stereotaxic coordinates used were as follows: antero-posterior, $-0.4 \mathrm{~mm}$ from bregma, $-1.25 \mathrm{~mm}$ lateral from the midline, and $-2.0 \mathrm{~mm}$ from bregma measured from the tip of the cannula guide (Paxinos and Franklin, 2001). Animals were habituated to dummy cannula removal and given 4 days of recovery and handling before the start of the experimental procedure. At the beginning of the study, target coordinates and proper cannula placement were verified by slowly injecting $1 \mu \mathrm{l}$ of methylene blue dye into the cannulas of the first four mice while they were under anesthesia. After waiting $5 \mathrm{~min}$ for the dye to circulate through the ventricles, the animals were killed. The brains were removed, sliced at the point of cannula entry, and target coordinates were verified.

\section{Tissue Isolation}

Dissection of the NAc was performed using a round-shape puncher. The NAc and hippocampus were immediately frozen in liquid nitrogen and stored at $-80{ }^{\circ} \mathrm{C}$ until RNA or DNA extracts were prepared.

\section{Measuring mRNA Levels by Real-Time PCR}

Total RNA was extracted from the NAc using RNeasy Mini Kit (QIAGEN, Hilden, Germany). Oligo-dT first-strand cDNA was synthesized from $0.4 \mu \mathrm{g}$ of total RNA using First-Strand cDNA Synthesis Kit (Fermentas, Burlington, Canada). Real-time PCR was performed using an ABI PRISM 7000 Sequence Detection System equipped with ABI PRISM 7000 SDS Software (Applied Biosystems, Bedford, MA, USA). Primers for mouse $P P 1 c$ were from SABiosciences (In Vitro Sweden AB, Stockholm, Sweden) and primers designed for mouse DNMT1, DNMT3A, DNMT3B, and $f o s B$ were as listed in Table 1 . PCR amplification was performed in a total reaction volume of $25 \mu \mathrm{l}$ in three parallels. The reaction mixture consisted of $1 \mu$ first-strand cDNA diluted template, $12.5 \mu \mathrm{l} 2 \times$ Master SYBR Green 
Table I Primers Used in DNA Methylation and Gene Expression Assays

\begin{tabular}{|c|c|}
\hline Target gene & Primer sequence $\left(5^{\prime}-3^{\prime}\right)$ \\
\hline \multicolumn{2}{|l|}{ mRNA RT-PCR primers } \\
\hline \multirow[t]{2}{*}{ fosB mRNA } & ACAGATCGACTTCAGGCGGA \\
\hline & GTTTGTGGGCCACCAGGAC \\
\hline \multirow[t]{2}{*}{ DNMTI mRNA } & CCCATGCATAGGTTCACTTCCTTC \\
\hline & TGGCTTCGTCGTAACTCTCTACCT \\
\hline \multirow[t]{2}{*}{ DNMT3A mRNA } & GCCGAATTGTGTCTTGGTGGATGACA \\
\hline & CCTGGTGGAATGCACTGCAGAAGGA \\
\hline \multirow[t]{2}{*}{ DNMT3B mRNA } & TCAGAAGGCTGGAGACCTCCCTCTT \\
\hline & TTCAGTGACCAGTCCTCAGACACGAA \\
\hline Glyceraldehyde 3-phosphate & CTGAGTATGTCGTGGAGTCTACTGG \\
\hline dehydrogenase (GAPDH) & GTCATATTTCTCGTGGTTCACACC \\
\hline \multirow[t]{2}{*}{$\beta$-Actin } & TCTCCATGTCGTCCCAGTTG \\
\hline & ATGGTGGGAATGGGTCAGAAG \\
\hline \multicolumn{2}{|c|}{ Methylation-specific RT-PCR primers } \\
\hline \multirow[t]{2}{*}{ fos $B$ methylated } & TGTTAATTITAGTITCGGGATAGC \\
\hline & TACGTCAAAAAAAATCCCTCG \\
\hline \multirow[t]{2}{*}{ fos B unmethylated } & ATTACATCAAAAAAAATCCСТCACT \\
\hline & TTAATITAGTIITGGGATAGTGT \\
\hline \multirow[t]{2}{*}{ PPIC methylated } & ACGAAAAAAACAAAATAACCGC \\
\hline & TITATGGGTTCGTAAAGAAGTTTC \\
\hline \multirow[t]{2}{*}{ PPIc unmethylated } & ACCACAAAAAAAACAAAATAACCAC \\
\hline & TाTATGGGTTTGTAAAGAAGTITG \\
\hline
\end{tabular}

RT-PCR Master Mix (Applied Biosystems), $10.5 \mu 1 \mathrm{H}_{2} 0$, and $1 \mu \mathrm{l}$ gene-specific $10 \mu \mathrm{M}$ PCR primer pair stock. Amplification specificity was controlled by a melting curve analysis and a gel electrophoresis of the PCR product. Serial dilutions (fivefold) from one wild-type sample total RNA were analyzed for each target gene and allowed to construct linear standard curves from which the concentrations of the test sample and efficiency of PCR reaction were calculated. Results were normalized to $\beta$-actin or GAPDH (glyceraldehyde-3-phosphate dehydrogenase) using the $\Delta \Delta \mathrm{CT}$ method (Livak and Schmittgen, 2001).

\section{Methylated DNA Immunoprecipitation Assay}

Methylated DNA immunoprecipitation (MeDIP) was performed using EpiQuik Tissue Methylated DNA Immunoprecipitation Kit (Epigentek Group, Brooklyn, NY, USA). Genomic DNA was extracted from frozen mouse NAc, sonicated into fragments ranging in size from 200 to $1000 \mathrm{bp}$, and divided into immunoprecipitated (IP) and input (IN) portions. IP DNA incubated with anti-5methylcytosine monoclonal antibody to bind methylated DNA, and the negative control was normal mouse IgG from the EpiQuik MeDIP Kit. Methylated DNA was subjected to quantitative real-time PCR using primers from SABiosciences for mouse PP1c and fosB. To evaluate the relative enrichment of target sequences after MeDIP, we calculated the ratios of the signals in the IP DNA vs IN DNA. The resulting values were standardized against the unmethylated control sequence GADPH, and the results of control group $(\mathrm{SAL}$ or $\mathrm{S}+\mathrm{S})$ were given the value of 1 and fold changes calculated.

\section{Methylation-Specific Real-Time PCR Analysis}

DNA was isolated from mouse NAc using QIAmp DNA Mini Kit (QIAGEN) and processed for bisulfite modification using Epitect Bisulfite Kit (QIAGEN). Quantitative real-time PCR was used to determine the DNA methylation status of the $P P 1 c$ and $f o s B$ genes. Methylation-specific PCR primers were designed using Methprimer software (www.urogene. org/methprimer). Methylation-specific and unmethylated PCR primers were designed to target putative CpG islands detected in silico in promoter or non-promoter regions of the $P P 1 c$ and $f o s B$ genes. Primer sequences are listed in Table 1. PCR reactions were performed as described above. $\mathrm{Ct}$ values were chosen within the linear range and the comparative $\mathrm{Ct}$ method was used to calculate differences in methylation between samples.

\section{Chromatin Immunoprecipitation (ChIP) Assay}

ChIP of genomic DNA associated with a methyl CpG binding protein 2 (MeCP2) was carried out according to the manufacturer's protocol (Millipore, Billerica, MA, USA). Mouse NAc was minced and cross-linked in $1 \%$ formaldehyde $(10 \mu \mathrm{l} / \mathrm{mg})$ for $15 \mathrm{~min}$ at $37^{\circ} \mathrm{C}$. Adding glycine stopped the cross-linking reaction and the tissue was washed twice in ice-cold PBS containing a protease inhibitor cocktail. The minced, fixed tissue was homogenized in SDS lysis buffer and the homogenate was sonicated to produce $200-1000 \mathrm{bp}$ genomic fragments. Following this, the resulting homogenate was centrifuged for $15 \mathrm{~min}$ at $13000 \mathrm{~g}$ and the supernatant was used for ChIP assay. Immunoprecipitations were carried out at $4{ }^{\circ} \mathrm{C}$ overnight with $5 \mu \mathrm{g}$ of rabbit polyclonal MeCP2 (Abcam, Cambridge, UK), negative control was anti-Rat IgG (Vector Laboratories, Burlingame, CA, USA) and positive control was anti-RNA Polymerase II from the EZ-ChIP Kit. A portion of the sonicated DNA was left untreated to serve as input control. Immune complexes were collected with protein A beads and, according to the manufacturer's protocol, sequentially washed two times with low salt buffer, high salt buffer, $\mathrm{LiCl}$ immune complex buffer, and TE buffer. Immunoprecipitated DNA was subjected to quantitative real-time PCR using ChIP primers from SABiosciences for mouse PP1C and fosB.

\section{Western Immunoblotting}

The NAc was lysed in $10 \mathrm{vol}(\mathrm{w} / \mathrm{vol})$ of lysis buffer $(50 \mathrm{mM}$ Tris- $\mathrm{HCl}$ (pH 7.4), $150 \mathrm{mM} \mathrm{NaCl}, 1 \%$ Triton X 100, and protease inhibitors), homogenized with ultrasound homogenizer, incubated $1 \mathrm{~h}$ at $+4{ }^{\circ} \mathrm{C}$, and centrifuged $(13000 \mathrm{~g}$ for $10 \mathrm{~min}$ at $4{ }^{\circ} \mathrm{C}$ ). The protein concentration was determined using RCDC Protein Assay (Bio-Rad, Hercules, CA, USA). The supernatants (50 $\mu \mathrm{g}$ of protein) were resolved by electrophoresis on $8 \%$ SDS-polyacrylamide gels. The membranes were blocked with $0.1 \%(\mathrm{w} / \mathrm{w})$ Tween 20/TBS (T-TBS) containing 5\% (w/w) non-fat dried milk at room temperature for $1 \mathrm{~h}$. After blocking, the membranes were incubated overnight with the anti-PP $1 \gamma 1$ polyclonal 
antibody ( $1: 1000$; Millipore) followed by incubation with biotinylated anti-rabbit IgM secondary antibody $(1: 1000)$ for $2 \mathrm{~h}$ and $\mathrm{ABC}$ solution for $30 \mathrm{~min}$. Mouse monoclonal anti$\beta$-actin antibody (Sigma-Aldrich, St Louis, MO, USA) was used to normalize PP1c immunoreactivity on the same blot and PP1c/ $\beta$-actin optical density (OD) ratio was calculated.

\section{Statistical Analysis}

Behavioral data of all experiments were analyzed using ANOVA for repeated measures, followed by Bonferroni post-test, as appropriate. Expression level of genes, MeDIP, and ChIP data were analyzed using one-way ANOVA with Bonferroni post-test. Differences in methylation-specific real-time PCR data were analyzed by two-way ANOVA with Bonferroni post-test. GraphPad Prism software was used for statistical analysis of the data. All data were expressed as mean \pm SEM, and significance was set at $p<0.05$.

\section{RESULTS}

\section{Cocaine-Induced Upregulation of DNMT3A and DNMT3B mRNA Levels in NAc and Hippocampus}

First, the effect of acute and repeated cocaine $(15 \mathrm{mg} / \mathrm{kg} /$ day) on adult mice was evaluated. Acute treatment with cocaine (AC) significantly increased the locomotor activity (Figure 1; two-way ANOVA repeated measures, interaction $\mathrm{F}_{2,35}=7.43, p=0.002$, treatment effect $\mathrm{F}_{2,35}=18.9$, $p<0.0001$, days effect $\mathrm{F}_{1,35}=28.81, p<0.0001$; Bonferroni post-test, $p<0.01)$. After a daily injection of cocaine for 7 days (RC), all of the mice displayed a significantly enhanced locomotion in response to the same dose of cocaine on day 7 compared with day $1(p<0.001)$, indicating a behavioral sensitization. The saline-treated mice (SAL) did not show any sensitization across test sessions $(p>0.05)$.

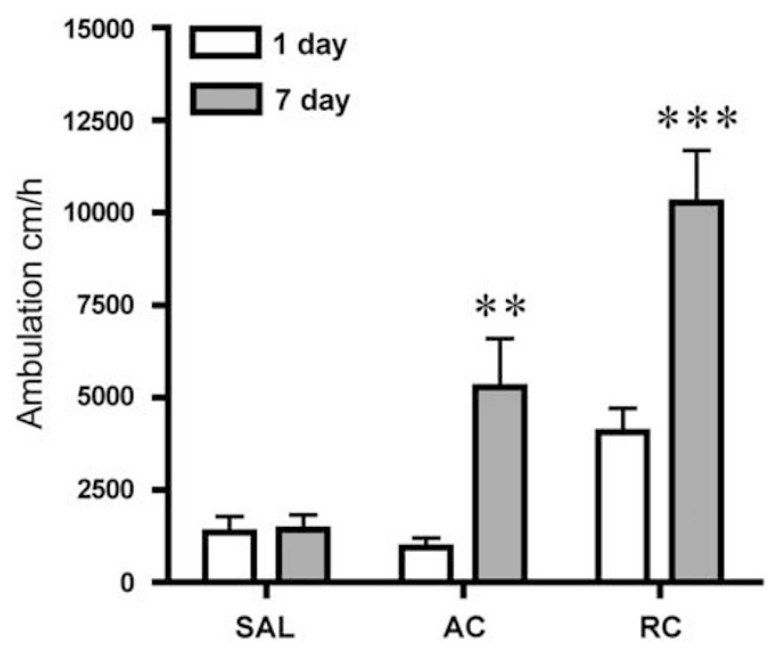

Figure I Cocaine-induced behavioral sensitization. Mice were treated daily for 7 days and ambulation was recorded for I h immediately after treatment. Treatment groups: SAL, mice were treated with saline; $A C$, mice were treated with saline for 6 days and with cocaine ( $15.0 \mathrm{mg} / \mathrm{kg}$ i.p.) on the seventh day; RC, mice were treated daily for 7 days with cocaine. Two-way ANOVA with repeated measures, followed by Bonferroni post-test, *** $<0.0$ I AC first vs seventh day, ${ }^{*} * * * 0<0.00$ I RC first vs seventh day, $n=1 \mathrm{I}$. Error bars indicate SEM.
It was recently reported that $D N M T 3 A$ and $D N M T 3 B$ gene expression was upregulated in the adult rat hippocampus following contextual fear conditioning, suggesting that DNMTs are dynamically regulated in the adult nervous system (Miller and Sweatt, 2007). Therefore, we investigated whether or not DNMTs mRNA levels are altered by acute and repeated cocaine treatment. We assayed mRNA levels of DNMT1, DNMT3A, and DNMT3B at 1.5 and $24 \mathrm{~h}$ after acute and repeated cocaine treatment in the NAc (Figure 2a-c). A single administration of cocaine displayed an increase in DNMT3A mRNA level $1.5 \mathrm{~h}$ after treatment, relative to animals treated with saline control (DNMT3A; one-way ANOVA, Bonferroni post-test, $p<0.01$ SAL vs AC, $n=12$ ) and DNMT3A and DNMT3B mRNA levels at $24 \mathrm{~h}$ after treatment (DNMT3A; one-way ANOVA, Bonferroni posttest, $p<0.001$ SAL vs AC, $n=12$; DNMT3B, $p<0.05$ SAL $v s$ $\mathrm{AC}, n=12$ ). However, the repeated treatment with cocaine did not change significantly mRNA levels of DNMT3A and $D N M T 3 B$ genes compared with saline control. Both acute and repeated cocaine treatment did not alter the mRNA level of DNMT1 gene.

In a parallel study, the effect of acute and repeated cocaine treatment on DNMT1, DNMT3A, and DNMT3B mRNA levels in the hippocampus at 1.5 and $24 \mathrm{~h}$ after treatment was determined (Supplementary Figure S1 A-C). We found that the acute and repeated cocaine treatment increased DNMT3A mRNA levels $1.5 \mathrm{~h}$ after treatment (oneway ANOVA, Bonferroni post-test, $p<0.001$ SAL $v s$ AC or $\mathrm{RC}, n=7)$ and DNMT3B expression level was increased in the hippocampus only after acute cocaine treatment (oneway ANOVA, Bonferroni post-test, $p<0.001 \mathrm{SAL} v s \mathrm{AC}$, $n=7)$. There were no changes in DNMT3A and DNMT3B mRNA levels $24 \mathrm{~h}$ after cocaine treatment compared with the saline control. Both acute and repeated cocaine treatment did not alter the mRNA level of DNMT1 gene in the hippocampus. Thus, the time course analysis demonstrated that DNMT3A and DNMT3B expression is dynamically regulated in the adult NAc and hippocampus in response to cocaine treatment.

\section{Altered Patterns of Gene Expression after Cocaine Treatment}

Increased expression of DNMT3A and DNMT3B might cause hypermethylation of certain gene promoters associated with $\mathrm{CpG}$ islands and consequently downregulate the expression of these genes. Therefore, a search was conducted for genes that show a diminished expression following cocaine treatment. Several genes were tested, such as brain-derived neurotrophic factor (BDNF), $P P 1 c$, fos $B$, and adenosine $A_{2 A}$ receptor $\left(A_{2 A} R\right)$, which participate in cocaine-induced neuroadaptations in the NAc and in silico analysis revealed $\mathrm{CpG}$ islands located within promoter regions.

Using quantitative real-time PCR we found that PP1c mRNA levels in the NAc were not altered $1.5 \mathrm{~h}$ after both acute and repeated cocaine treatment (Figure 3a). However, $24 \mathrm{~h}$ after treatment in both acute and repeated cocaine groups, the PP1c mRNA levels were significantly decreased compared with the saline control (one-way ANOVA, Bonferroni post-test, $p<0.05$ AC or RC vs SAL, $n=12$ ). To further confirm PP1c mRNA downregulation in the NAc, 

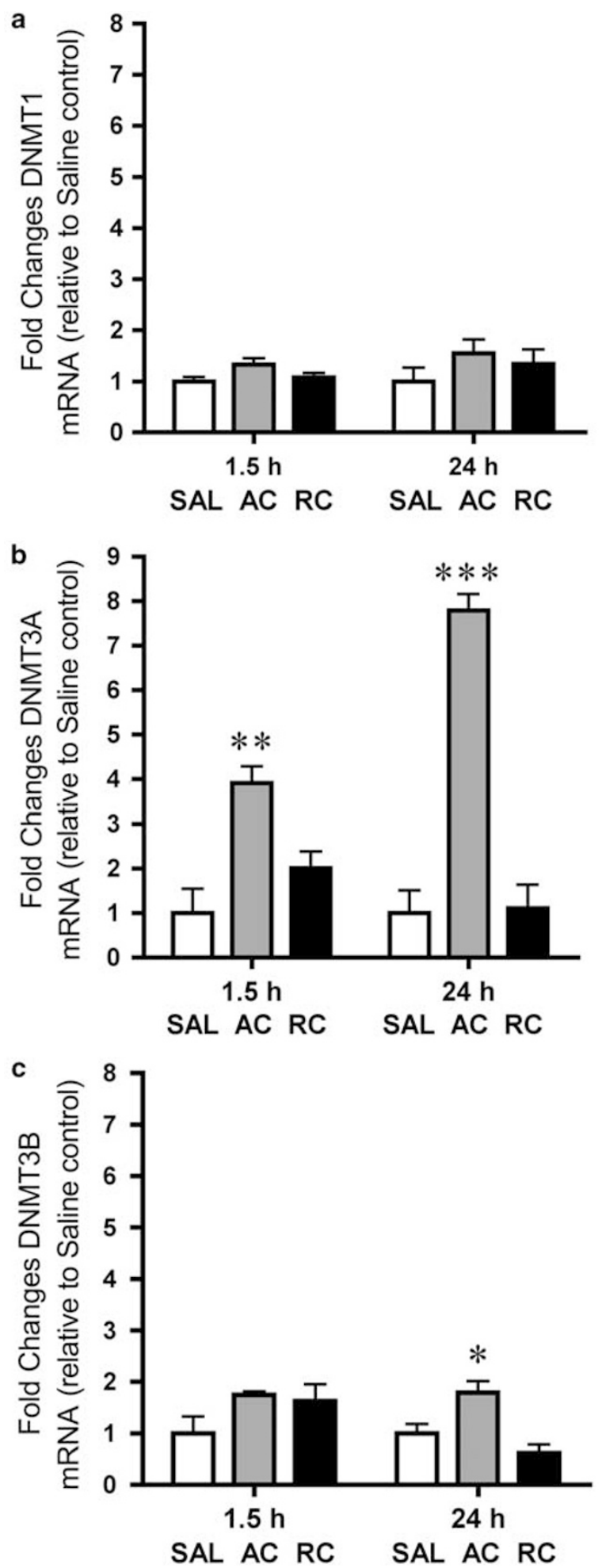

Figure 2 Acute cocaine treatment was associated with an upregulation of DNMT3A and DNMT3B mRNA levels in the NAc, using a quantitative realtime PCR. (a-c) Cocaine effect on DNMTI, DNMT3A, and DNMT3B mRNA levels at 1.5 and $24 \mathrm{~h}$ after treatment in the NAc. One-way ANOVA, followed by Bonferroni post-test, $* p<0.05$, *** $<0.00$ I, **** $p<0.000$ I compared with saline (SAL) group, $n=11$. Error bars indicate SEM.

western blot analysis was performed. We found that both acute and repeated cocaine treatment resulted in a significantly lower PP1c protein level $24 \mathrm{~h}$ after treatment

(Figure 3b; one-way ANOVA, Bonferroni post-test, $p<0.05$ AC or RC $v s$ SAL, $n=9$ ).

As expected, it was found that acute and repeated cocaine treatment resulted in upregulation of fos $B$ mRNA level $1.5 \mathrm{~h}$ after treatment (Figure 3c; one-way ANOVA, Bonferroni post-test, $p<0.001 \mathrm{AC}$ or RC $v s \mathrm{SAL}, n=12$ ). However, there were no significant changes $24 \mathrm{~h}$ after acute and repeated cocaine treatment. Acute and repeated cocaine treatment also resulted in significant downregulation of $A_{2 A} R$ mRNA level $1.5 \mathrm{~h}$ after treatment (Figure 3d; one-way ANOVA, Bonferroni post-test, $p<0.0001$ AC or RC vs SAL, $n=7)$. However, there were no significant changes in the mRNA level of $B D N F$ gene after cocaine treatment in the NAc (Supplementary Figure S2). As we were interested in studying cocaine-induced long-lasting effects, for future DNA methylation studies, PP1c and fosB (as reference) genes were selected.

\section{Cocaine Treatment Changed DNA Methylation at PP1c and fosB Promoter Regions}

To shed further light on the role of DNA methylation in cocaine-induced behavioral sensitization, we next looked for an aberrant DNA methylation during acute and repeated cocaine treatments. First, we evaluated cocaine-induced changes of DNA methylation patterns at the PP1c promoter region using MeDIP assay. We found that both acute and repeated cocaine treatment resulted in $P P 1 c$ promoterassociated $\mathrm{CpG}$ island hypermethylation $24 \mathrm{~h}$ after treatment (Figure 4b; one-way ANOVA, Bonferroni post-test, $p<0.001$ AC or RC $v s$ SAL, $n=6$ ).

To verify cocaine-induced hypermethylation at the PP1c promoter region, methylation-specific quantitative realtime PCR (MSP qPCR) was employed. Data generated using MSP qPCR demonstrated that acute and repeated cocaine treatment elicited DNA hypermethylation associated with the $P P 1 c$ promoter region $24 \mathrm{~h}$ after treatment (Figure $4 \mathrm{a}$ and c; two-way ANOVA, interaction $\mathrm{F}_{2,66}=8.34, p=0.0006$, treatment effect $\mathrm{F}_{2,66}=2.77, \quad p=0.0699$, methylation effect $\mathrm{F}_{1,66}=31.24, \quad p<0.0001$; Bonferroni post-test, $p<0.05$ methylated AC vs methylated SAL, and $p<0.001$ methylated RC $v s$ methylated SAL). As a DNA methylation control, levels of unmethylated DNA within the PP1c promoter after acute and repeated cocaine treatment was measured, using primer sequences designed to amplify unmethylated $\mathrm{CpG}$ island sites. Thus, MeDIP and MSP qPCR methods demonstrated that acute and repeated cocaine treatment resulted in hypermethylation at the PP1c promoter region $24 \mathrm{~h}$ after treatment.

In correlation with upregulated fos $B$ mRNA levels, we found hypomethylation at the fos $B$ promoter $1.5 \mathrm{~h}$ after acute and repeated cocaine treatment, using MeDIP assay (Figure 5a and b; one-way ANOVA; Bonferroni post-test, $p<0.001 \mathrm{AC}$ or RC $v s \mathrm{SAL}, n=6$ ). To further confirm that acute and repeated cocaine administration altered DNA methylation at the promoter regions of $P P 1 c$ and fosB genes, ChIP assay was performed. Consistent with the MeDIP and MSP qPCR results, ChIP analysis demonstrated that acute and repeated cocaine treatment increased by 1.8 - to 2 -fold the PP1C promoter-associated MeCP2 binding $24 \mathrm{~h}$ after treatment in the NAc (Figure 6a; one-way ANOVA, Bonferroni post-test, $p<0.01$ AC or RC vs SAL, $n=6$ ). 

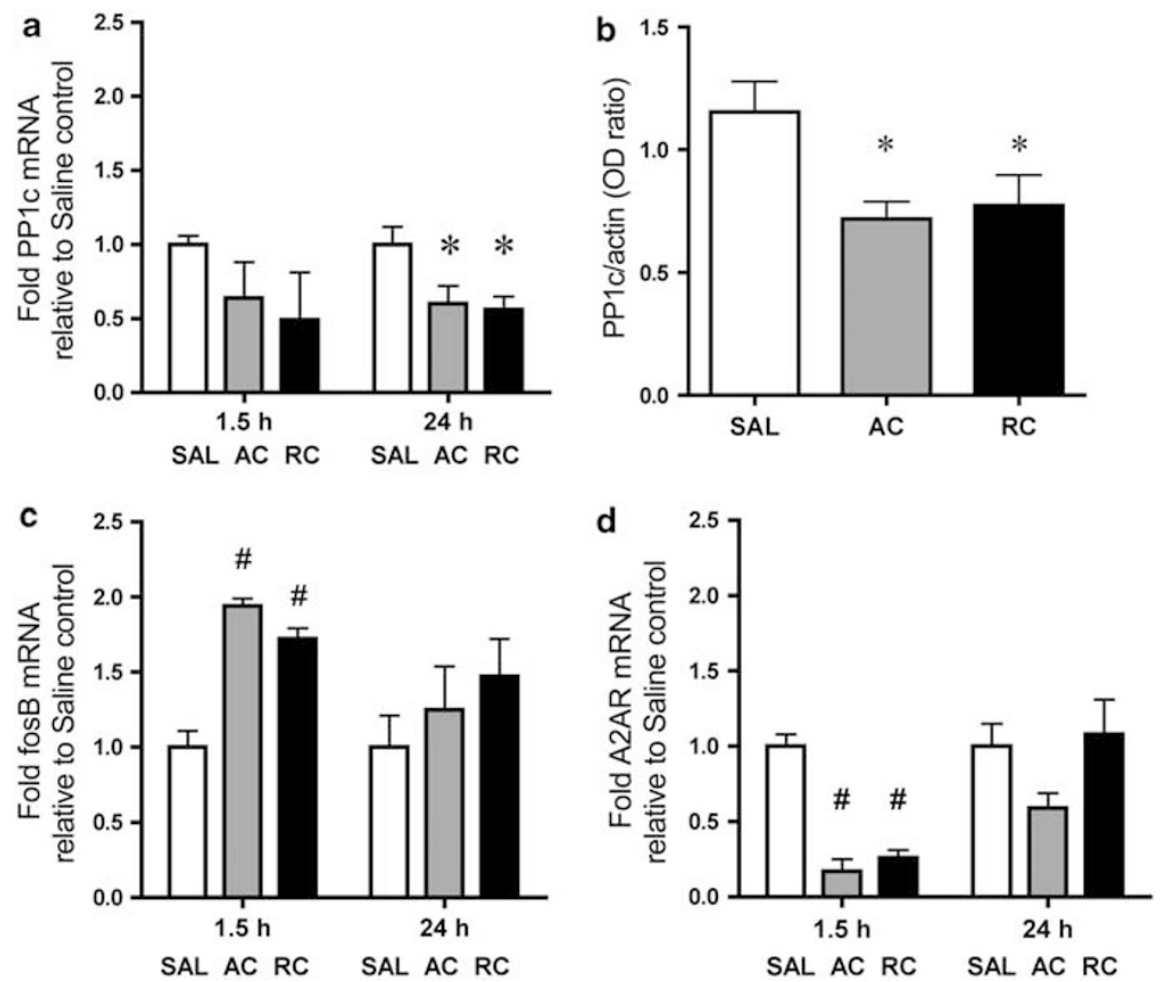

Figure 3 Altered patterns of $P P I C$, fosB, and $A 2 A R$ gene expressions after cocaine treatment in the NAc. (a) The effect of acute (AC) and repeated cocaine (RC) administration on PPIc mRNA levels at 1.5 and $24 \mathrm{~h}$ after treatment, using quantitative real-time PCR. (b) $A C$ and RC treatment resulted in decrease of PPI c protein level $24 \mathrm{~h}$ after treatment in the NAc, using western blot analysis. (c) The effect of $A C$ and RC administration on fosB mRNA levels, using quantitative real-time PCR. (d) The effect of $A C$ and RC administration on A2AR mRNA levels, using quantitative real-time PCR. One-way ANOVA, followed by Bonferroni post-test, ${ }^{*} p<0.05,{ }^{\#} p<0.00$ I compared with saline (SAL) group, $n=1$ I. Error bars indicate SEM. OD, optical density.

However, in the fos $B$ promoter, acute and repeated cocaine treatment was associated with a significant decrease in $\mathrm{MeCP} 2$ binding compared with the saline control at $1.5 \mathrm{~h}$ after treatment (Figure 6b; one-way ANOVA, Bonferroni post-test, $p<0.001 \mathrm{AC}$ or RC vs SAL, $n=6$ ). Taken together, these data support the idea that alteration of DNA methylation in promoter regions controls gene expression because there is a correlation of increased $P P 1 c$ promoterassociated $\mathrm{CpG}$ island hypermethylation with increased $\mathrm{MeCP} 2$ binding and with decreased PP1c gene transcription and opposite effect at the fos $B$ promoter.

\section{Zebularine Inhibited DNA Hypermethylation at PP1c Promoter and Delayed Cocaine-Induced Behavioral Sensitization}

As we found that cocaine induced DNMT3A and DNMT3B expression and PP1c promoter hypermethylation, the next goals in this study were to assess the effect of DNMT inhibitor on cocaine-induced molecular changes and development of behavioral sensitization. We selected the DNMT inhibitor zebularine for testing based on reported data (Miller and Sweatt, 2007; Lubin et al, 2008). To correlate the molecular changes with cocaine-induced locomotor sensitization, a dose of zebularine (300 ng per $0.5 \mu$ l, i.c.v.) that did not affect basal locomotor activity and decreased DNA methylation at the PP1c promoter region at $1.5 \mathrm{~h}$ after acute treatment (Figure $7 \mathrm{a}$; $t$-test, $p=0.034$, $n=4$ ) was selected from our pilot study.
For the co-treatment experiment, all mice received i.c.v. infusion of saline or zebularine followed, after $20 \mathrm{~min}$, by i.p. saline or cocaine $(15 \mathrm{mg} / \mathrm{kg})$. Locomotor activity was recorded for $60 \mathrm{~min}$ immediately after the last i.p. injection (see Materials and Methods). Repeated saline and cocaine $(\mathrm{S}+\mathrm{C})$ treatment for 7 days displayed a significantly enhanced locomotion on day 7 compared with that of day 1 (Figure 7b; two-way ANOVA with repeated measures, interaction $F_{3,39}=5.69, p=0.0025$, treatment effect $\mathrm{F}_{3,39}=15.98, \quad p<0.0001$, days effect $\mathrm{F}_{1,39}=10.26, \quad p=$ 0.0027 ; Bonferroni post-test, $p<0.001 \mathrm{~S}+\mathrm{C}$ day 1 vs day $7)$. However, mice co-treated with zebularine and cocaine $(Z+C)$ did not show any sensitization on day 7 compared with day $1 \quad(p>0.05)$. There was also no behavioral sensitization after repeated zebularine and saline $(Z+S)$ treatments $(p>0.05)$. Therefore, our results suggest that the inhibition of DNMTs with zebularine did not affect acute cocaine-induced locomotor activity, but instead delayed cocaine-induced behavior sensitization in mice.

Finally, we studied for molecular evidence to confirm that zebularine infusions (i.c.v.) before cocaine treatment altered DNA methylation level at the PP1c promoter region in the NAc.

Using MeDIP assay we found that repeated cocaine treatment $(\mathrm{S}+\mathrm{C})$ induced, at the $P P 1 c$ promoter region, DNA hypermethylation $24 \mathrm{~h}$ after treatment compared with the saline control group $(S+S)$, and repeated zebularine and cocaine $(\mathrm{Z}+\mathrm{C})$ co-treatment avoided this effect (Figure 8a; one-way ANOVA, Bonferroni post-test, 

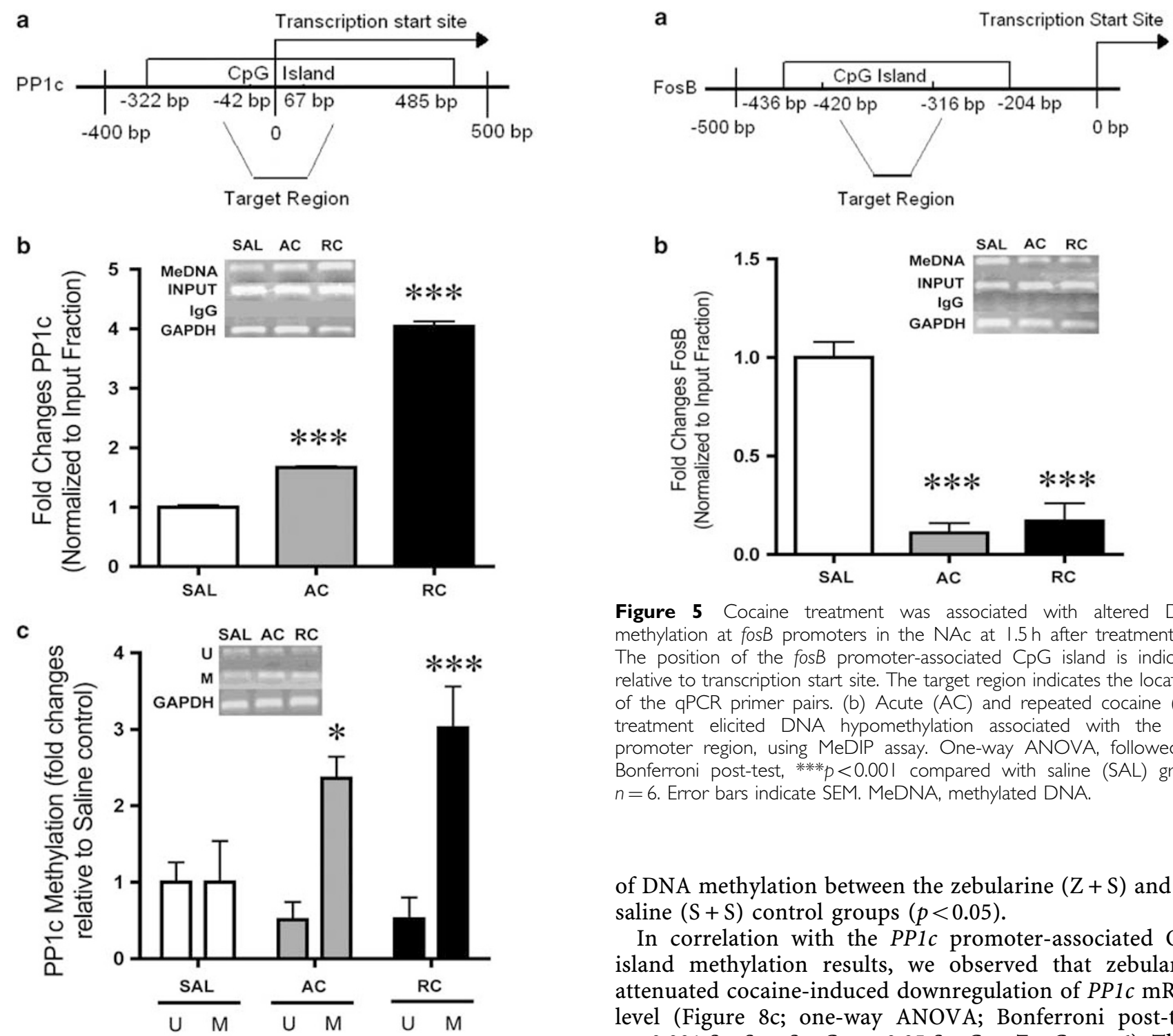

Figure 4 Cocaine treatment was associated with altered DNA methylation at PPIC promoters in the NAc at $24 \mathrm{~h}$ after treatment. (a) The position of the PPIc promoter-associated CpG island is indicated relative to transcription start site. The target region indicates the locations of MSP qPCR primer pairs. (b) Acute (AC) and repeated cocaine (RC) treatment elicited DNA hypermethylation associated with the PP/c promoter region, using MeDIP assay. One-way ANOVA, followed by Bonferroni post-test, ${ }^{* * *} p<0.00$ I compared with saline $(S A L)$ group, $n=6$. (c) $A C$ and $R C$ treatment elicited hypermethylation associated with the PPIc promoter region, using MSP qPCR. Two-way ANOVA followed by Bonferroni post-test, * $p<0.05$, **** $p<0.00$ I compared with methylated $\mathrm{SAL}$ group, $n=11$. Error bars indicate SEM. M, methylated; MeDNA, methylated DNA; $U$, unmethylated.

$p<0.001 \mathrm{~S}+\mathrm{S}$ vs $\mathrm{S}+\mathrm{C}, p<0.001 \mathrm{~S}+\mathrm{C}$ vs $\mathrm{Z}+\mathrm{C}, n=6)$. Similarly, MSP qPCR analysis demonstrated that there was a significant decrease of DNA methylation associated with the $P P 1 c$ promoter region in the $\mathrm{Z}+\mathrm{C}$ group compared with the $\mathrm{S}+\mathrm{C}$ group (Figure 8b; two-way ANOVA, interaction $\mathrm{F}_{3,45}=80.8, p<0.0001$, treatment effect $\mathrm{F}_{3,45}=39.0, p<$ 0.0001 , methylation effect $\mathrm{F}_{1,45}=42.8, p<0.0001$; Bonferroni post-test, $p<0.001$ methylated $\mathrm{S}+\mathrm{C} v s$ methylated $\mathrm{Z}+\mathrm{C}$ ). Interestingly, in both studies we found significant changes

Figure 5 Cocaine treatment was associated with altered DNA methylation at fos $B$ promoters in the NAc at $1.5 \mathrm{~h}$ after treatment. (a) The position of the fos B promoter-associated $\mathrm{CpG}$ island is indicated relative to transcription start site. The target region indicates the locations of the GPCR primer pairs. (b) Acute (AC) and repeated cocaine (RC) treatment elicited DNA hypomethylation associated with the fos $B$ promoter region, using MeDIP assay. One-way ANOVA, followed by Bonferroni post-test, $* * * * 0.00$ I compared with saline $(S A L)$ group, $n=6$. Error bars indicate SEM. MeDNA, methylated DNA.

of DNA methylation between the zebularine $(\mathrm{Z}+\mathrm{S})$ and the saline $(S+S)$ control groups $(p<0.05)$.

In correlation with the PP1c promoter-associated $\mathrm{CpG}$ island methylation results, we observed that zebularine attenuated cocaine-induced downregulation of $P P 1 c$ mRNA level (Figure 8c; one-way ANOVA; Bonferroni post-test, $p<0.001 \mathrm{~S}+\mathrm{S} v s \mathrm{~S}+\mathrm{C}, p<0.05 \mathrm{~S}+\mathrm{C} v s \mathrm{Z}+\mathrm{C}, n=6)$. These results indicate that the inhibition of DNMTs by zebularine reverses cocaine-induced $P P 1 c$ gene hypermethylation and mRNA downregulation in the NAc.

\section{DISCUSSION}

In this study we have produced four main findings. First, it was found that acute cocaine treatment results in an upregulated mRNA of DNMT3A and DNMT3B in the NAc. Second, it was observed that acute and repeated cocaine treatment is associated with DNA hypermethylation and transcriptional downregulation of the $P P 1 c$ gene, and hypomethylation and transcriptional activation of the fos $B$ gene in the NAc. Third, it was found that i.c.v. infusions of the DNMT inhibitor zebularine, before cocaine treatment, decreased levels of DNA hypermethylation at the PP1c promoter-associated $\mathrm{CpG}$ island and attenuated $P P 1 c$ mRNA downregulation in the NAc. Finally, zebularine and cocaine co-treatment were found to delay development of cocaine-induced behavioral sensitization. These observations suggest that DNA hyper- and hypomethylation may be 

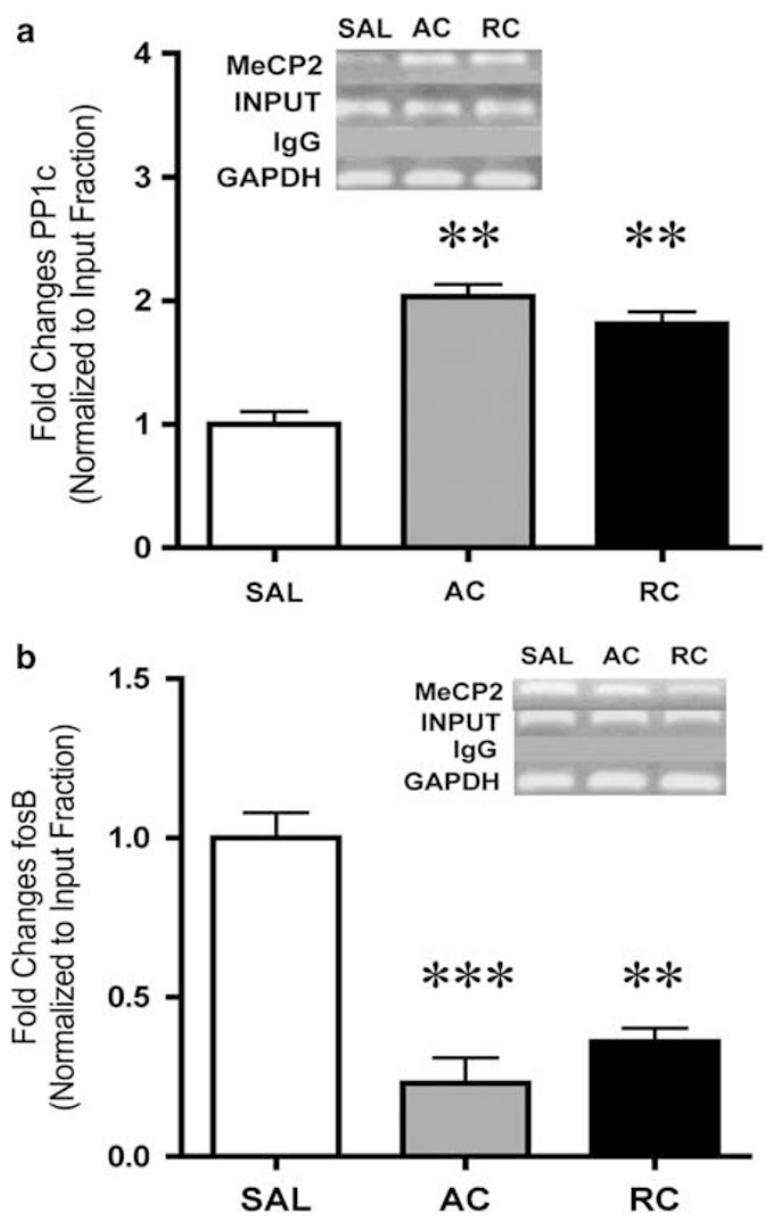

Figure 6 Altered patterns of MeCP2 binding at PP / $c$ and fos B promoter regions in the NAc, using ChIP assay. (a) Acute (AC) and repeated cocaine (RC) treatment increased MeCP2 binding at the PPIC promoter region relative to the saline (SAL) group at $24 \mathrm{~h}$ after treatment. (b) $A C$ and $R C$ treatment decreased $\mathrm{MeCP} 2$ binding at the fos $\mathrm{B}$ promoter region at $1.5 \mathrm{~h}$ after treatment. One-way ANOVA, Bonferroni post-test, $* * * 0.01$, **** $p<0.00$ I relative to SAL, $n=6$. Error bars indicate SEM.

important processes during the development of cocaineinduced behavioral sensitization.

Psychostimulants such as cocaine and amphetamine induce neuroadaptations through regulation of gene expression. New concepts have emerged concerning the role of chromatin modification as a requirement for the regulation of gene expression in neurons. In this study we focused on the function of DNA methylation in cocainealtered gene expression in the NAc. Previous findings have implied that the function of DNMTs in the CNS might be involved in DNA repair and neurodegeneration (Brooks et al, 1996; Endres et al, 2000; Fan et al, 2001; Endres et al, 2001) and that misregulation of DNA methylation and DNMTs might be involved in cognitive disorders such as schizophrenia, Rett syndrome, and Fragile X mental retardation (Veldic et al, 2004; Amir et al, 1999; Sutcliffe et al, 1992).

Recently, Miller and Sweatt (2007) showed that DNA methylation levels were rapidly and dynamically regulated in the hippocampus following the associative training paradigm of contextual fear conditioning. They also found that mRNAs for DNMT3A and DNMT3B were upregulated
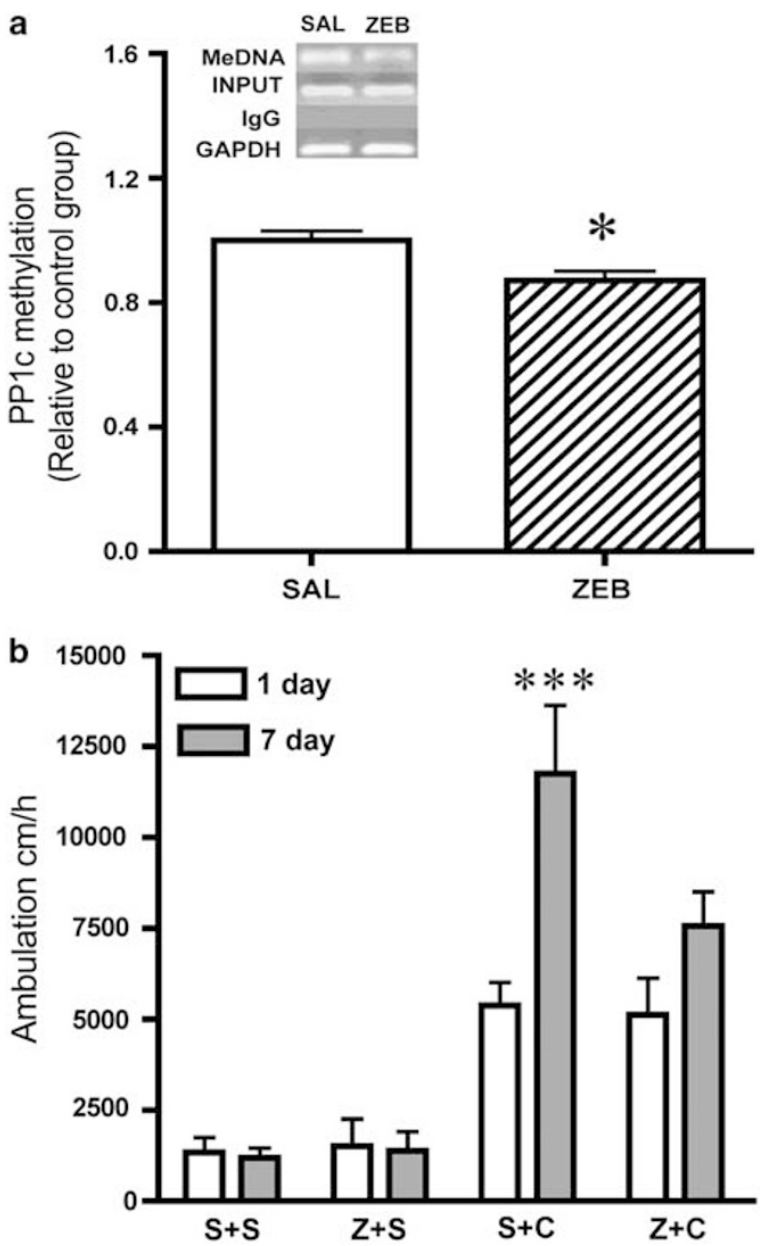

Figure 7 Inhibition of DNMT by zebularine delayed cocaine-induced behavioral sensitization. (a) Acute zebularine (ZEB) (300 ng per $0.5 \mu$ l, i.c.v.) treatment elicited DNA hypomethylation associated with the PP/C promoter region at $1.5 \mathrm{~h}$ after treatment in the NAc, using MeDIP assay. $T$-test, $* p=0.034, n=4$. (b) Mice were treated with cocaine $(15.0 \mathrm{mg} / \mathrm{kg}$, i.p.) alone or co-treated with zebularine $(300 \mathrm{ng}$ per $0.5 \mu$ l, i.c.v.) daily for 7 days, and their ambulation was recorded for I $\mathrm{h}$ immediately after treatment. Mice were treated with saline $(0.5 \mu$ l, i.c.v. $)+$ saline $(0.1 \mathrm{ml}$ per $10 \mathrm{~g}$ body weight, i.p. $)(\mathrm{S}+\mathrm{S})$; zebularine i.c.v. + saline i.p. $(Z+S)$; saline i.c.v. + cocaine i.p. $(S+C)$; or zebularine i.c.v. + cocaine i.p. $(Z+C)$. Two-way ANOVA with repeated measures, followed by Bonferroni post-test, ***** $<<0.00$ I $S+C$ first vs seventh day, $n=7-12$. Error bars indicate SEM. MeDNA, methylated DNA.

in area CA1 of the hippocampus following fear conditioning. The results of the present study were comparable in that they demonstrated that acute cocaine treatment was associated with an upregulation of DNMT3A and DNMT3B genes in the NAc and hippocampus (Figure $2 \mathrm{~b}$ and $\mathrm{c}$; Supplementary Figure S1B and C, respectively). However, no significant changes of DNMT1 mRNA levels in the NAc and hippocampus were found, suggesting that cocaine induces rather de novo than maintenance of DNA methylation. It was also found that DNMT3A gene expression achieved the highest level after acute cocaine treatment and it diminished after repeated cocaine exposure. In relation to DNMT3A and DNMT3B expression levels in the NAc, cocaine-induced changes in the hippocampus were more dynamic as there were no significant changes $24 \mathrm{~h}$ after treatment. 

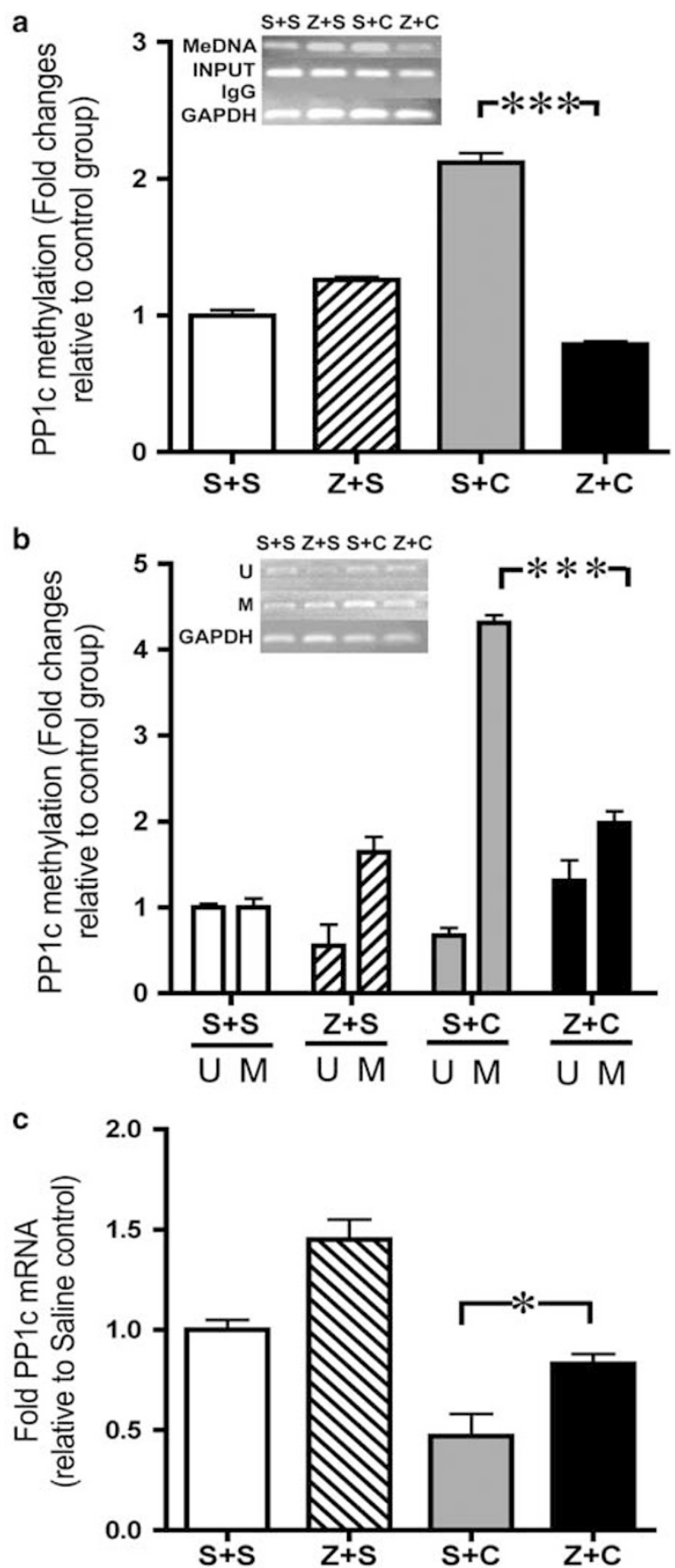

Figure 8 Inhibition of DNMT by zebularine altered DNA methylation at the PP/c promoter region $24 \mathrm{~h}$ after treatment in the NAc. Mice were treated with saline $(0.5 \mu$ l, i.c.v. $)+$ saline $(0.1 \mathrm{ml}$ per $10 \mathrm{~g}$ body weight, i.p. $)$ $(S+S)$; zebularine i.c.v. + saline i.p. $(Z+S)$; saline i.c.v. + cocaine i.p. $(S+C)$; or zebularine i.c.v. + cocaine i.p. $(Z+C)$. (a) Repeated $Z+C$ co-treatment decreased DNA methylation level associated with the PPIc promoter relative to the $S+C$ group. (b) Repeated $Z+C$ treatment decreased DNA methylation level associated with the PPIc promoter relative to the $S+C$ group. Two-way ANOVA followed by Bonferroni post-test, ***** $p<0.00$ I methylated $S+C$ vs methylated $Z+C, n=5-7$. (c) The blockade of PPIC methylation by zebularine was associated with an enhanced PPIc mRNA level. One-way ANOVA followed by Bonferroni post-test $*$ p $<0.05 \mathrm{~S}+\mathrm{C}$ vs $Z+C, n=5-7$. Error bars indicate SEM. M, methylated; $U$, unmethylated; MeDNA, methylated DNA.

The signal transduction processes that might control cocaine-induced DNMT expression in the adult CNS are unknown at present. Although DNA methylation is a part of the regulation of gene expression, it infers that there may be some overlap of intracellular signaling pathways with other chromatin modification mechanisms, such as histone acetylation and phosphorylation. In the adult, CNS chromatin modification is governed by various intracellular signaling pathways, including the Ras-mitogen-activated protein kinase (MAPK/ERK) cascade (Renthal and Nestler, 2008; Brami-Cherrier et al, 2009). Several studies demonstrated that targeting the Ras signaling pathway with drugs such as methotrexate and inhibitors of MAPK/ERK decreases DNA methylation in malignant hematological diseases and colon cancer cells, indicating a causal relationship between Ras signaling and DNA methylation (MacLeod et al, 1995; Philips, 2004; Morgan et al, 2007; Lu et al, 2007; Diaz-Flores and Shannon, 2007).

In recent years, the MAPK/ERK signaling cascade has been implicated in responses to most drugs of abuse (Berke and Hyman, 2000; Nestler, 2001; Fasano and Brambilla, 2002; Girault et al, 2007). Several studies have demonstrated that in response to cocaine, the MAPK/ERK and the downstream mitogen- and stress-activated protein kinase 1 (MSK1) controls an early phase of histone H3 phosphorylation at the $c$-fos promoter in striatal neurons (BramiCherrier et al, 2005). MSK1 action may be potentiated by the concomitant inhibition of PP1 by nuclear translocation of dopamine and cAMP-regulated phosphoprotein $\mathrm{Mr}$ 32000 (DARPP-32) (Stipanovich et al, 2008). Cocaine also phosphorylates the transcription factor cAMP response element binding protein (CREB) via the MAPK/ERK-MSK1 cascade (Swank and Sweatt, 2001; Levine et al, 2005). This phosphorylation and activation of CREB recruits CREB binding protein (CBP), which is a histone acetyltransferase that regulates local chromatin structure as part of CREBdependent activation of nuclear gene transcription. Therefore, we speculate that cocaine-induced activation of the Ras signaling pathway might trigger both DNA methylation and histone modifications.

Using MeDIP and MSP qPCR methods, we demonstrated that DNMT activation results in increased methylation of the PP1c promoter region in the NAc after acute and repeated cocaine treatment (Figure $4 \mathrm{~b}$ and $\mathrm{c}$ ). It was also found that PP1c promoter region hypermethylation corresponded with decreased expression levels of both mRNA and protein (Figure 3a). These changes were also related to an overall increase in methyl CpG binding domain proteins, such as MeCP2 binding in the PP1c promoter region (Figure 6a). It has been shown experimentally that methylation of DNA brings about general deacetylation of histones $\mathrm{H} 3$ and $\mathrm{H} 4$, prevents methylation at histone $\mathrm{H} 3 \mathrm{~K} 4$, and induces methylation of histone H3 K9 (Shahbazian and Grunstein, 2007; Li et al, 2007; Kouzarides, 2007; Patra and Szyf, 2008). Therefore, we speculate that MeCP2 can recruit co-repressor complexes to methylated PP1c promoter regions, including histone-modifying enzymes such as histone deacetylases (HDAC) and histone methyltransferases.

Repression of PP1C may result in several effects on the intracellular signal transduction level; for example, inhibition of $P P 1 c$ has been shown to increase phosphorylation of the $\alpha$-amino-3-hydroxy-5-methyl-4-isoxazolepropionic acid 
(AMPA) receptor subunit GluR1 and $\mathrm{Ca} 2+/$ calmodulindependent protein kinase II (Genoux et al, 2002). Reduced PP1 may have important effects for transcriptional regulation by CREB through the ability of PP1 to complex with HDAC. Canettieri et al (2003) demonstrated that a HDAC1PP1 complex represses CREB activation under basal conditions and dephosphorylates CREB to return the system to baseline after a stimulus. This suggests that repression of PP1 is crucial in providing phosphorylated CREB with the capacity to recruit CBP to the promoter, at which time histones become acetylated and help to drive the transcription of particular genes. Taken together, repression of the PP1c gene via methylation of promoter regions should allow aberrant phosphorylation of crucial receptors, protein kinases, and transcription factors during cocaineinduced neuroadaptations.

Previous studies have shown that expression of Fosfamily proteins (c-Fos, FosB, Fra-1, and Fra2) is rapidly induced in the NAc after acute exposure to drugs of abuse (Hope et al, 1994). This induction is transient, lasting only 4-12 h after drug exposure. Because acute cocaine treatment caused in fosB promoter-associated $\mathrm{CpG}$ island hypomethylation (Figure 5b), and decreased $\mathrm{MeCP} 2$ binding (Figure 6b) and fosB mRNA upregulation (Figure 3c), this suggests that cocaine may also induce DNA demethylation and increase expression in certain genes. At present, there is no clearly identified DNA demethylase in mammals and the biochemical mechanism for active DNA demethylation is unknown (Ooi and Bestor, 2008). Several reports discovered that the demethylation process is initiated by DNMT3A and DNMT3B (Kangaspeska et al, 2008; Métivier et al, 2008). These studies proposed that DNMT3A and DNMT3B possess deaminase activity and that both enzymes are involved in a dynamic demethylation-methylation pathway that operates during gene transcription (Kangaspeska et al, 2008; Métivier et al, 2008). Recently, Ma et al (2009) proposed that active DNA demethylation can be potentially carried out through three mechanisms: direct removal of the methyl group from the 5-methylcytosine base, base excision of 5-methylcytosine through DNA glycosylases, and nucleotide excision of 5-methylcytosine through endonucleases. Base and nucleotide excisions are followed by similar subsequent fill-in repair with unmethylated cytosine.

In this study we demonstrate that DNMT inhibition by zebularine blocked hypermethylation on the PP1c promoter region and delayed the development of cocaine-induced behavioral sensitization. The decrease of PP1c hypermethylation was triggered using i.c.v. infusion of zebularine and it was sufficient to re-establish PP1c gene expression in the NAc. Zebularine is a potent inhibitor, affecting all DNMT subtypes (Weisenberger et al, 2004; Marquez et al, 2005). However, we were unable to determine which subtype of DNMT is important for the development of behavioral sensitization. It is possible that both DNMT3A and DNMT3B work together to hypermethylate the promoterassociated $\mathrm{CpG}$ islands and to then transcriptionally repress these genes, aiding in the development of behavioral sensitization.

In Figure $7 \mathrm{a}$ we show that a single dose of zebularine caused hypomethylation at the promoter of $P P 1 \mathrm{c}$ at $1.5 \mathrm{~h}$ after treatment. However, the effect of repeated zebularine
$(\mathrm{Z}+\mathrm{S})$ administration resulted in $P P 1 c$ promoter region hypermethylation $24 \mathrm{~h}$ after last treatment (Figure $8 \mathrm{a}$ and b). Based on zebularine pharmacokinetics (Holleran et al, 2005), we speculate that $24 \mathrm{~h}$ after the last administration of zebularine $(Z+S)$, the DNMT inhibition effect is ended. Therefore, it is possible that a slight increase of methylation in PP1c promoter-associated $\mathrm{CpG}$ island in $\mathrm{Z}+\mathrm{S}$ groups (Figure 8 and $\mathrm{b}$ ) is caused by a compensatory increase of DNMT activity after inhibition by zebularine. Despite slight hypermethylation at $P P 1 c$, we found 1.5-fold increased mRNA level in the $Z+S$ group compared with the saline control $(S+S$, Figure $8 \mathrm{c}$ ), suggesting that smaller changes of DNA methylation may not alter gene transcription. Other DNA methylation-associated epigenetic mechanisms (histone acetylation, phosphorylation, and methylation) may also alter gene transcription activity. Our results demonstrated that zebularine blocked hypermethylation at the $P P 1 c$ promoter region and downregulation of $P P 1 c$ mRNA level. We speculate that in addition to PP1c, zebularine may also inhibit hypermethylation in promoter-associated $\mathrm{CPG}$ islands of other genes, re-establish these gene transcriptions, and therefore inhibit cocaine-induced neuroplasticity in the brain.

At the behavioral level, we found that repeated coadministration of zebularine with cocaine markedly delayed the development of behavioral sensitization, whereas zebularine by itself did not affect locomotor activity. Interestingly, zebularine did not modify acute cocaine effect, suggesting that the promoter region hypermethylation might be an important underlying mechanism for altered gene expression during development of behavioral sensitization. Therefore, we hypothesize that zebularine via normalization of gene transcription at cellular level stabilized neuronal network function and therefore delayed the development of psychostimulant-induced behavioral sensitization. As DNA methylation has an important role in learning and memory formation (Miller and Sweatt, 2007), zebularine may also delay cocaine-induced behavioral sensitization by inhibiting DNA methylation in the hippocampus and altering associated learning and memory formation.

In conclusion, our study demonstrated that cocaine treatment might cause a dynamic increase in DNMT3A and DNMT3B expression and consequently hypermethylation of promoter-associated CpG islands in the NAc. It is not known which subtype of DNMT is important for DNA methylation during the development of behavioral sensitization. However, our results suggest that cocaine induces rather de novo than maintenance DNA methylation. The results of DNMT inhibitor zebularine and cocaine cotreatment experiments demonstrated that zebularine effectively inhibited cocaine-induced PP1c hypermethylation and delayed the development of behavioral sensitization. Therefore, DNMT3A and DNMT3B may be important molecular targets for modifying psychostimulant-induced neurochemical and behavioral effects.

\section{ACKNOWLEDGEMENTS}

We thank Dr G Tasa for help with methylation-specific realtime PCR and MeDIP analysis and A Harrison for critical 
reading of the paper. This study was supported by the Estonian Science Foundation (Grant ETF7585), University of Tartu (Grant PARFR08903), and European Regional Development Fund.

\section{DISCLOSURE}

The authors declare no conflict of interest.

\section{REFERENCES}

Amir RE, Van den Veyver IB, Wan M, Tran CQ, Francke U, Zoghbi HY (1999). Rett syndrome is caused by mutations in X-linked MECP2, encoding methyl-CpG-binding protein 2. Nat Genet 23: 185-188.

Berke JD, Hyman SE (2000). Addiction, dopamine, and the molecular mechanisms of memory. Neuron 25: 515-532.

Bestor TH (2000). The DNA methyltransferases of mammals. Hum Mol Genet 9: 2395-2402.

Bird A (2002). DNA methylation patterns and epigenetic memory. Genes Dev 16: 6-21.

Brami-Cherrier K, Roze E, Girault JA, Betuing S, Caboche J (2009). Role of the ERK/MSK1 signalling pathway in chromatin remodelling and brain responses to drugs of abuse. J Neurochem 108: $1323-1335$.

Brami-Cherrier K, Valjent E, Hervé D, Darragh J, Corvol JC, Pages $\mathrm{C}$ et al (2005). Parsing molecular and behavioral effects of cocaine in mitogen- and stress-activated protein kinase-1deficient mice. J Neurosci 25: 11444-11454.

Brooks PJ, Marietta C, Goldman D (1996). DNA mismatch repair and DNA methylation in adult brain neurons. $J$ Neurosci 16: 939-945.

Canettieri G, Morantte I, Guzman E, Asahara H, Herzig S, Anderson SD et al (2003). Attenuation of a phosphorylationdependent activator by an HDAC-PP1 complex. Nat Struct Biol 10: 175-181.

Diaz-Flores E, Shannon K (2007). Targeting oncogenic Ras. Gene Dev 21: 1989-1992.

Fasano S, Brambilla R (2002). Cellular mechanisms of striatumdependent behavioral plasticity and drug addiction. Curr $\mathrm{Mol}$ Med 2: 649-665.

Genoux D, Haditsch U, Knobloch M, Michalon A, Storm D, Mansuy IM (2002). Protein phosphatase 1 is a molecular constraint on learning and memory. Nature 418: 970-975.

Girault JA, Valjent E, Caboche J, Herve D (2007). ERK2: a logical and gate critical for drug-induced plasticity? Curr Opin Pharmacol 7: 77-85.

Endres M, Fan G, Meisel A, Dirnagl U, Jaenisch R (2001). Effects of cerebral ischemia in mice lacking DNA methyltransferase 1 in post-mitotic neurons. NeuroReport 12: 3763-3766.

Endres M, Meisel A, Biniszkiewicz D, Namura S, Prass K, Ruscher $\mathrm{K}$ et al (2000). DNA methyltransferase contributes to delayed ischemic brain injury. J Neurosci 20: 3175-3181.

Fan G, Beard C, Chen RZ, Csankovszki G, Sun Y, Siniaia M et al (2001). DNA hypomethylation perturbs the function and survival of CNS neurons in postnatal animals. J Neurosci 21: 788-797.

Goll MG, Bestor TH (2005). Eukaryotic cytosine methyltransferases. Annu Rev Biochem 74: 481-514.

Holleran JL, Parise RA, Joseph E, Eiseman JL, Covey JM, Glaze ER et al (2005). Plasma pharmacokinetics, oral bioavailability, and interspecies scaling of the DNA methyltransferase inhibitor, zebularine. Clin Cancer Res 11: 3862-3868.

Hope BT, Nye HE, Kelz MB, Self DW, Iadarola MJ, Nakabeppu Y et al (1994). Induction of a long-lasting AP-1 complex composed of altered Fos-like proteins in brain by chronic cocaine and other chronic treatments. Neuron 13: 1235-1244.

Jones PA, Baylin SB (2002). The fundamental role of epigenetic events in cancer. Nat Rev Genet 3: 415-428.

Kangaspeska S, Stride B, Metivier R, Polycarpou-Schwarz M, Ibberson D, Carmouche RP et al (2008). Transient cyclical methylation of promoter DNA. Nature 452: 112-115.

Koob GF, Bloom FE (1988). Cellular and molecular mechanisms of drug dependence. Science 242: 715-723.

Kouzarides T (2007). Chromatin modifications and their function. Cell 128: 693-705.

Kumar A, Choi KH, Renthal W, Tsankova NM, Theobald DE, Truong HT et al (2005). Chromatin remodeling is a key mechanism underlying cocaine-induced plasticity in striatum. Neuron 48: 303-314.

Levine AA, Guan Z, Barco A, Xu S, Kandel ER, Schwartz JH (2005). CREB-binding protein controls response to cocaine by acetylating histones at the fosB promoter in the mouse striatum. Proc Natl Acad Sci USA 102: 19186-19191.

Li B, Carey M, Workman JL (2007). The role of chromatin during transcription. Cell 128: 707-719.

Livak KJ, Schmittgen TD (2001). Analysis of relative gene expression data using real-time quantitative PCR and the 2(-Delta Delta C(T)) method. Methods 25: 402-408.

Lu R, Wang X, Chen Z-F, Sun D-F, Tian X-Q, Fang J-Y (2007). Inhibition of extracellular signal regulated kinase mitogenactivated protein kinase pathway decrease DNA-methylation in colon cancer cells. J Biol Chem 282: 12249-12259.

Lubin FD, Roth TL, Sweatt JD (2008). Epigenetic regulation of BDNF gene transcription in the consolidation of fear memory. J Neurosci 28: 10576-10586.

MacLeod AR, Rouleau J, Szyf M (1995). Regulation of DNA methylation by the Ras signaling pathway. J Biol Chem 270: 11327-11337.

Ma DK, Guo JU, Ming GL, Song H (2009). DNA excision repair proteins and Gadd45 as molecular players for active DNA demethylation. Cell Cycle 8: 1526-1531.

Marquez VE, Kelley JA, Agbaria R, Ben-Kasus T, Cheng JC, Yoo CB et al (2005). Zebularine: a unique molecule for an epigenetically based strategy in cancer chemotherapy. Ann NY Acad Sci 1058: 246-254.

Métivier R, Huet G, Gallais R, Finot L, Petit F, Tiffoche C et al (2008). Dynamics of estrogen receptor-mediated transcriptional activation of responsive genes in vivo: apprehending transcription in four dimensions. Adv Exp Med Biol 617: 129-138.

Miller CA, Sweatt JD (2007). Covalent modification of DNA regulates memory formation. Neuron 53: 857-869.

Morgan MA, Ganser A, Reuter CW (2007). Targeting the RAS signaling pathway in malignant hematologic diseases. Curr Drug Target 8: 217-235.

Nestler EJ, Aghajanian GK (1997). Molecular and cellular basis of addiction. Science 278: 58-63.

Nestler EJ (2001). Molecular basis of long-term plasticity underlying addiction. Nat Rev Neurosci 2: 119-128.

Ooi SK, Bestor TH (2008). The colorful history of active DNA demethylation. Cell 133: 1145-1148.

Patra SK, Szyf M (2008). DNA methylation-mediated nucleosome dynamics and oncogenic Ras signaling. Insights from FAS, FAS ligand and RASSF1A. FEBS J 275: 5217-5235.

Paxinos G, Franklin KBJ (2001). The Mouse Brain in Stereotaxic Coordinates. Academic Press: San Diego, CA.

Philips MR (2004). Methotrexate and Ras methylation: a new trick for an old drug? Sci STKE 225: pe13.

Pierce RC, Kalivas PW (1997). A circuitry model of the expression of behavioral sensitization to amphetamine-like psychostimulants. Brain Res Rev 25: 192-216.

Renthal W, Carle TL, Maze I, Covington III HE, Truong HT, Alibhai I et al (2008). Delta FosB mediates epigenetic 
desensitization of the c-fos gene after chronic amphetamine exposure. J Neurosci 28: 7344-7349.

Renthal W, Kumar A, Xiao G, Wilkinson M, Covington III HE, Maze I et al (2009). Genome-wide analysis of chromatin regulation by cocaine reveals a role for sirtuins. Neuron 62: 335-348.

Renthal W, Maze I, Krishnan V, Covington III HE, Xiao G, Kumar A et al (2007). Histone deacetylase 5 epigenetically controls behavioral adaptations to chronic emotional stimuli. Neuron 56: 517-529.

Renthal W, Nestler EJ (2008). Epigenetic mechanisms in drug addiction. Trends Mol Med 14: 341-350.

Robertson KD, Wolffe AP (2000). DNA methylation in health and disease. Nat Rev Genet 1: 11-19.

Robinson TE, Berridge KC (1993). The neural basis of drug craving: an incentive-sensitization theory of addiction. Brain Res Rev 18: 247-291.

Shahbazian MD, Grunstein M (2007). Functions of sitespecific histone acetylation and deacetylation. Annu Rev Biochem 76: 75-100.

Shen HY, Kalda A, Yu L, Ferrara J, Zhu J, Chen JF (2008). Additive effects of histone deacetylase inhibitors and amphetamine on histone $\mathrm{H} 4$ acetylation, cAMP responsive element binding protein phosphorylation and DeltaFosB expression in the striatum and locomotor sensitization in mice. Neuroscience 157: 644-655.

Siedlecki P, Zielenkiewicz P (2006). Mammalian DNA methyltransferases. Acta Biochim Pol 53: 245-256.

Singal R, Ginder GD (1999). DNA methylation. Blood 93: 4059-4070.

Stipanovich A, Valjent E, Matamales M, Nishi A, Ahn JH, Maroteaux $M$ et al (2008). A phosphatase cascade by which rewarding stimuli control nucleosomal response. Nature 453: 879-884.

Sutcliffe JS, Nelson DL, Zhang F, Pieretti M, Caskey CT, Saxe D et al (1992). DNA methylation represses FMR-1 transcription in fragile X syndrome. Hum Mol Genet 1: 397-400.

Swank MW, Sweatt JD (2001). Increased histone acetyltransferase and lysine acetyltransferase activity and biphasic activation of the ERK/RSK cascade in insular cortex during novel taste learning. J Neurosci 21: 3383-3391.

Veldic M, Caruncho HJ, Liu WS, Davis J, Satta R, Grayson DR et al (2004). DNA-methyltransferase 1 mRNA is selectively overexpressed in telencephalic GABAergic interneurons of schizophrenia brains. Proc Natl Acad Sci USA 101: 348-353.

Weisenberger DJ, Velicescu M, Cheng JC, Gonzales FA, Liang G, Jones PA (2004). Role of the DNA methyltransferase variant DNMT3b3 in DNA methylation. Mol Cancer Res 2: 62-72.

Supplementary Information accompanies the paper on the Neuropsychopharmacology website (http://www.nature.com/npp) 